\title{
Regulatory reform and banking diversity: reassessing Basel 3
}

\section{Giuliana Birindelli ${ }^{1}$ D Paola Ferretti ${ }^{2} \cdot$ Giovanni Ferri $^{3} \cdot$ Marco Savioli $^{4}$}

Received: 17 December 2020 / Accepted: 29 December 2021 / Published online: 2 March 2022

(c) The Author(s) 2022, corrected publication 2022

\begin{abstract}
We investigate whether and how strongly Basel 3 chief innovations jointly affected in different ways individual Eurozone banks' stability (z-score) across six business models (BMs). We study this issue in the initial years when adaptation was most intense (2011-2014) and the Eurozone underwent a phase with sovereign crises abated by ECB policies easing financial conditions. In parallel, we run this exercise over 2000-2010 data, a time frame over which Basel 3 did not apply yet to see through the eyes of the regulator. Irrespective of BMs, we identify the leverage ratio as the most effective driver of banks' stability. However, the impact on Z-score of Basel 3 chief drivers does not seem to differ significantly on 2011-2014 vs. 2000-2010. Next, interactions with banks' BMs suggest that Basel 3 innovations improve $\mathrm{z}$-scores the most at traditionally focused banks (cooperative and savings banks), vis-à-vis diversified banks. Our results suggest Basel regulatory decisions were questionable. First, the front loading of the increased minimum capital requirements vs. the backloading of the leverage ratio phasing in may have lured banks from credit to financial assets. Second, our findings support the desirability of revising the current "one-size-fits-all" European prudential framework, which disregards BMs.
\end{abstract}

Keywords Bank regulation · Bank diversity · Basel 3 - Banks' business model · Financial stability

JEL classification G21 · G28

Extended author information available on the last page of the article 


\section{Background}

The theme of banks' business models (BMs) has been increasingly emphasised in recent years for various reasons, among which the international financial and economic crisis and the reform of the capital adequacy framework (Basel 3). The resulting prudential regulation aims to improve the banking sector's ability to absorb shocks arising from financial and economic stress, thus trying to reduce spillover from the financial sector to the real economy, improve risk management and governance, and strengthen banks' transparency and disclosure (BCBS 2011, 2013, 2014).

The basic question is whether Basel 3 has achieved its key aim of reducing excess risk taking and ensuring banks' stability independently of business focus (banks' specialisation or business model). Our paper contributes in this respect. Indeed, while Basel 3 is multifaceted, featuring four chief regulatory innovations - capital requirement (CR), precisely capital buffer, leverage ratio (LR), liquidity coverage ratio (LCR), and net stable funding ratio (NSFR) - most studies have focused on just one or two of the four innovations failing to capture the overall thrust of Basel 3 on banks' risk taking (e.g., Bordeleau and Graham 2010; Blundell-Wignall et al. 2013; Dietrich et al. 2014; Vázquez and Federico 2015). Thus, our first task is offering a comprehensive analysis of the impact of Basel 3 by considering whether and how all four innovations jointly affect banks' riskiness.

In addition, over time, banks' business conduct has changed, reflecting both "voluntary" strategic management decisions and the uncertain international scenario. In unison, experiences from the crisis show that banks' soundness may also be undermined by their type of activity. This makes it even more crucial understanding the business model banks adopt as a strategic tool to improve efficiency and competitiveness as well as stability, thereby sustainably contributing to economic growth. That issue must be weighed also considering the role Basel 3 innovations play in reshaping BMs. For example, many banks downsized their securitization exposures, particularly affected by the new regulatory requirements, while others reduced certain lending activities in high-risk sectors (e.g., commercial real estate) or curbed volatile wholesale funding. In other words, progress in reshaping BMs is continuing and will advance further along a refocusing on core activities and markets.

Nonetheless, if on one side Basel 3 (in addition to other internal and external factors, e.g. weak profitability and overall economic conditions) affects banks' BMs, on the other side a key question is whether it can reach its goals, in primis ensuring banks' overall soundness. Our paper explores this line of research by analysing whether and how strongly the Basel 3 requirements have different impacts on the stability of banks with different specialisation. Indeed, we argue that banking diversity, which may be expressed in terms of banks' size (small versus large), ownership (Shareholder Value-SHV - vs. Stakeholder Value-STV - orientation) and business focus (retail versus investment banking), was disregarded by Basel 3 regulators, as it is a "one-size-fits-all" regulatory paradigm in Europe where, differently from the US, all banks must comply with such regulatory framework.

Based on the widely-held belief that Basel 3 does not sufficiently consider banks' diversity (Altunbas et al. 2011; Ayadi et al. 2012), we focus on the consequences-in terms of stability, expressed by the $z$-score indicator —of complying to the prudential 
framework by banks working under various BMs. As different BMs may entail different risk structures, we ask whether it may be appropriate to reflect this in regulation by specifying different requirements to better align with banks' business characteristics (Ayadi et al. 2012).

Existing studies on the effects of Basel 3 on the risk of banks with different BMs are largely based on the analysis of one or more regulatory measures; other studies focus on the relationship between regulation and BMs and on BMs and risk (see Sect. 2). However, to the best of our knowledge, the studies focusing on the mix of regulation-business model — stability are still scarce and differ from our approach because they do not examine the Basel four innovations jointly.

This paper contributes to the existing literature for various reasons.

Firstly, our analysis assesses the impact that Basel 3 requirements produce on the $z$-score, as a proxy for banks' stability, when banks' BMs are considered. This is the main contribution of our paper, whose insights should be crucial for regulators and policymakers. By examining the impact of Basel 3 requirements on the stability of banks with different BMs, our paper broadly contributes to gauge whether the current prudential framework may achieve its goal of promoting financial stability irrespective of each bank's business model. Hence, we propose that the "one-size-fits-all" regulatory paradigm should be reviewed, considering also banks' business features, to enhance the overall effectiveness of the current framework in ensuring financial stability (e.g., Kupiec 2007; Kasselaki and Tagkalakis 2014).

Moreover, we use a longer time series (2000-2014) than other studies (e.g., Ayadi et al. 2012; Blundell-Wignall and Roulet 2013) and split it into two subperiods (2000-2010 vs. 2011-2014) to control for Basel 3 regulatory effect and thereby show the evolution of the relationship among Basel 3, BMs and stability. Our test of the differential impact of the new Basel 3 measures on banking soundness is run on the subsample ot the years 2011-2014, after the new Accord was finalised, to see the immediate effect of the measures. However, we present also the estimations on the subsample 2000-2010 as it helps to see through the eyes of the regulator when deciding the measures and to test the robustness of our results.

Also, while other studies focus on big banks only (e.g., Altunbas et al. 2011; Blundell-Wignall and Roulet 2013), our large sample sheds light on banks of different size (large, medium and small banks), helping to gauge the impact of Basel 3 standards by controlling for a rich set of attributes.

Lastly, we focus on the Eurozone, which is particularly interesting in light of its increasing uniformity and comparability in terms of supervision. This allows us to limit institutional heterogeneity across our banks. At the same time, however, referring to this area makes our results in part potentially influenced also by the coinciding sovereign debt crisis and the policies by the ECB to ease the Eurozone financial conditions. ${ }^{1}$

Our overall findings identify the key driver of banks' stability in the leverage ratio, which exhibits a positive and highly significant impact on stability. Among liquidity standards, the net stable funding ratio seems to improve stability but not significantly, while we detect contradictory relationships between liquidity coverage ratios and

${ }^{1}$ We are grateful to an anonymous referee for raising this point that we try to control in our analyses below. 
z-scores. Across BM types, our evidence suggests that a more traditionally focused activity may prove a positive driver of stability under Basel 3. Particularly the interactions with banks' BMs suggest that Basel 3 innovations improve z-scores the most for cooperative and savings banks vis-à-vis other banks that should instead be considered the major culprits of the financial turmoils of the $2000 \mathrm{~s}$.

The remainder of the paper is organized as follows. Section 2 hosts a concise general review of the relevant literature on banks' BMs. Section 3 describes the sample used in the analysis. In Sect. 4, we justify dependent and explanatory variables, supporting our selection with specific references to the literature. Section 5 presents the methodology. Section 6 provides the empirical results, and Sect. 7 reports our robustness tests. Finally, Sect. 8 concludes.

\section{General literature review}

Lately, business models (BMs) analysis has gained new traction in banking.

Some studies focus on the link between banks' BMs and stability, measured - as for us - by the $z$-score. For example, Köhler (2015) shows a positive diversification effect on the $z$-score of a higher share of non-interest income, even though such an effect tends to decrease as size increases. In a previous study, Köhler (2014) finds a close correlation between non-interest income and the $z$-score depending on the adopted BM. Specifically, a positive diversification effect on stability is confirmed for retail-oriented banks but not for investment ones. Demirgüç-Kunt and Huizinga (2009) study how banks' income and funding mixes influence banks' $z$-score and return. Traditional banks, relying on interest income and deposit funding, show less risk taking (and hence greater stability) than banks mainly oriented towards noninterest income generation and wholesale funding. Chiaramonte et al. (2015), examining the link between the $z$-score and banks' BMs - classified into commercial, savings and cooperative banks-, find that cooperative banks' BM is more stable than the others. Moreover, this bank type contributes to stabilize large banks, particularly during periods of financial distress. Following previous reports (Ayadi et al. 2011, 2012; Ayadi and De Groen 2014), based on various risk indicators, including the $z$-score, Ayadi et al. (2015) identify focused-retail banks as safest, while wholesale and investment banks presented greater risk during the financial crisis.

Another stream of analysis targets the impact of regulation on BMs. For example, EBA (2015) argues the Basel 3 implications for banks' BMs. It focuses on the consequences that the CRR/CRDIV capital requirements, Basel 3 liquidity coverage ratio and net stable funding ratio (in addition to structural reforms) could exert on banks' BMs. It turns out that compliance with the Basel regulation could strongly affect banks' profitability and their ability to support the real economy by providing it credit. Ötker-Robe and Pazarbasioglu (2010) consider the Basel prudential regulation by examining the BMs of large and complex financial institutions. The authors state that "the new Basel package is not business model neutral", as the most relevant effects deriving from tighter provisions for capital and liquidity emerge for investment and universal banks. 
Other studies highlight the link between banks' BMs and one or more Basel 3 requirements, particularly capital measures, on one side, and liquidity indicators, on the other. Vázquez and Federico (2015) distinguish large, internationally active, vs. domestically oriented institutions and classify the latter into commercial, savings and cooperative banks. They explore systematic differences in the link between leverage and structural liquidity, and the consequent probability of failure across bank types. Capital shortages emerge as the determining factor for the failure of global banks (e.g., Russo et al. 2020) and, within the subsample of domestic intermediaries, savings banks are most vulnerable in terms of adequate capital buffers. Blundell-Wignall et al. (2013) show that leverage ratios predict large banks' risk (measured by the distance-to-default-DTD) better than tier 1 capital ratios. However, the leverage ratio cannot compensate for the great impact of BM characteristics on DTD. Furthermore, the appropriate level of the leverage ratio and the trade-off between it and regulatory capital should be addressed, depending on the specific kind of activity that banks conduct and therefore their BM. Moving on to liquidity requirements, Dietrich et al. (2014) focus on the NSFR, examining its features and drivers. They find that also the NSFR is not business model neutral, as it is strongly affected by the features of BMs: a higher NSFR associates with a more interest-oriented activity rather than those more related to asset management or investment banking. By the same token, King (2013) finds a negative correlation between net interest margin and NSFR for universal banks with highly diversified funding and highly concentrated trading assets. Again, Vázquez and Federico (2015) show that weakness in structural liquidity, resulting in low NSFR, plays a key role in the failure of domestic banks. Within this subsample, commercial banks are most vulnerable to liquidity problems. EBA (2015) shows a high degree of LCR dispersion within BMs, probably due to the low correlation between this indicator and the BM adopted by the bank. More broadly, Bordeleau and Graham (2010) show that the relationship between liquid assets and profitability varies across banks' BMs. A more traditional banking model, in fact, associates with higher profits in case of less liquid assets. Hence, the authors support appropriately tailored regulatory liquidity standards to achieve financial stability.

\section{Sample}

We consider Eurozone banks along the six business models (BMs) identified in the Bankscope database: commercial banks, bank holdings and holding companies, cooperative banks, investment banks, real estate and mortgage banks, and savings banks. Restricting to Eurozone countries allows greater uniformity in assessing the impact of Basel 3 requirements on the risk of banks with different BMs. Also, increasingly uniform supervision suggests that Eurozone banks are not too dissimilar, so omitted variables should not endanger the validity of our estimations.

The extent of our time horizon (2000-2014) should ensure a complete view of the issue by allowing us to detect the effects of the international financial and economic crisis on bank risk, before and after Basel 3 rules did apply. To this end, we split the data into two subperiods: prior to Basel 3 release (2000-2010) and after the issue of Basel 3 to the year 2014, in the initial years when adaptation took shape (2011-2014). 
Table 1 Sample distribution of the banks by business model for each country: 2000-2014

\begin{tabular}{|c|c|c|c|c|c|c|c|}
\hline Country & $\begin{array}{l}\text { Com- } \\
\text { mercial } \\
\text { banks }\end{array}$ & $\begin{array}{l}\text { Bank holdings } \\
\text { \& holding } \\
\text { companies }\end{array}$ & $\begin{array}{l}\text { Coop- } \\
\text { erative } \\
\text { banks }\end{array}$ & $\begin{array}{l}\text { Invest- } \\
\text { ment } \\
\text { banks }\end{array}$ & $\begin{array}{l}\text { Real } \\
\text { estate \& } \\
\text { mortgage } \\
\text { banks }\end{array}$ & $\begin{array}{l}\text { Savings } \\
\text { banks }\end{array}$ & Total \\
\hline Austria & 71 & 7 & 110 & 7 & 17 & 106 & 318 \\
\hline Belgium & 30 & 7 & 7 & 4 & 2 & 6 & 56 \\
\hline Cyprus & 17 & 4 & 2 & 6 & 0 & 1 & 30 \\
\hline Estonia & 8 & 0 & 0 & 3 & 0 & 0 & 11 \\
\hline Finland & 24 & 1 & 2 & 0 & 3 & 4 & 34 \\
\hline France & 121 & 5 & 82 & 20 & 30 & 27 & 285 \\
\hline Germany & 136 & 16 & 971 & 29 & 42 & 517 & 1,711 \\
\hline Greece & 8 & 1 & 1 & 2 & 0 & 0 & 12 \\
\hline Ireland & 15 & 2 & 0 & 12 & 6 & 0 & 35 \\
\hline Italy & 85 & 12 & 421 & 19 & 4 & 37 & 578 \\
\hline Latvia & 20 & 0 & 0 & 0 & 0 & 0 & 20 \\
\hline Lithuania & 11 & 0 & 0 & 0 & 0 & 0 & 11 \\
\hline Luxembourg & 66 & 8 & 2 & 5 & 1 & 2 & 84 \\
\hline Malta & 9 & 0 & 1 & 5 & 0 & 1 & 16 \\
\hline Netherlands & 33 & 12 & 1 & 4 & 7 & 1 & 58 \\
\hline Portugal & 25 & 8 & 2 & 5 & 1 & 4 & 45 \\
\hline Slovak Republic & 12 & 1 & 0 & 1 & 2 & 2 & 18 \\
\hline Slovenia & 17 & 0 & 2 & 1 & 0 & 2 & 22 \\
\hline Spain & 51 & 5 & 60 & 9 & 1 & 28 & 154 \\
\hline Total & 759 & 89 & 1,664 & 132 & 116 & 738 & 3,498 \\
\hline
\end{tabular}

This table shows the sample distribution of the banks by business model for each Eurozone country over the entire sample period (2000-2014)

Source: Bankscope

Our final sample consists of 3,498 Eurozone banks: 759 commercial banks, 89 bank holdings and holding companies, 1,664 cooperative banks, 132 investment banks, 116 real estate and mortgage banks, and 738 savings banks. Table 1 shows the sample distribution of the banks by BM for each country over all the years. Germany is the country with the highest number of banks in each BM. Italy comes second for cooperative banks (421) and the Netherlands for bank holdings and holding companies (12). France is second for commercial banks (121), investment banks (20) and real estate and mortgage banks (30), while Austria for savings banks (106).

\section{Description of the variables and connections with the literature}

\subsection{Dependent variable}

Our dependent variable is bank stability, measured by the $z$-score calculated as follows: 


$$
Z-\text { Score }_{i t}=\frac{R O A A_{i t}+C A R_{i t}}{S D R O A A_{i}}
$$

where $R O A A_{i t}$ is the return on average assets of bank $i$ in year $t, C A R_{i t}$ is the ratio of total equity to total assets of bank $i$ in year $t$ and $S D R O A A_{i}$ represents the standard deviation of $R O A A$ of bank $i$ over the sample period, as computed by others (Laeven and Levine 2009).

Defined as the number of standard deviations a bank's ROAA has to fall below its expected value to deplete its equity and make the bank insolvent, the $z$-score is a popular risk measure in the banking and financial stability literature (Boyd and Graham 1986; Hannan and Hanweck 1988; Boyd and Runkle 1993; Maechler et al. 2007; Demirgüç-Kunt and Huizinga 2009; Laeven and Levine 2009; Beck et al. 2013; Delis et al. 2014; Fang et al. 2014; a refinement of the $z$-score is presented by Lepetit and Strobel 2015). The measure is inversely related to the probability of a bank's insolvency: higher $z$-score values show greater bank stability and, therefore, lower risk.

Compared to other bank soundness proxies, typically market-based risk measures, $z$-score's appeal stems from its relative simplicity and from the fact that it can be derived from the balance sheet; hence, as an accounting indicator, it can also be used for unlisted financial institutions (e.g., Lepetit and Strobel 2015). At the same time, for cross-country analyses, it improves on accounting-based indicators related to credit and/or liquidity risks, such as non-performing loans, interest margins and capital adequacy ratios, which vary along nation-specific factors and rules (DemirgüçKunt et al. 2013). Yet, some problems arise with its calculation. First, the $z$-score (and its components: ROAA, CAR and $S D R O A A$ ) disregards the short-term nature of risk and thus the volatility of profits; this depends chiefly on using annual data, the most popular bank-level information available in Bankscope. Second, as a bank's risk and its other characteristics are related, endogeneity may be an issue (Delis et al. 2014). However, the panel structure of our data allows us to handle the issue convincingly (a robustness check counters this criticism).

Since the $z$-score is highly skewed, following the literature, we use its natural logarithm ( $\ln \_$), which is normally distributed (Laeven and Levine 2009; Chiaramonte et al. 2015). Also, we winsorize $z$-scores at $0.5 \%$ to discard outliers.

Table 2 displays $\ln \_z$ and its components across BMs and periods.

Savings banks show the highest $z$-score, followed by cooperative banks; compared to other bank types, the lower riskiness of these two business models mostly owes to lower volatility of returns (lower $S D R O A A$ ) rather than higher ROAA and/or CAR. Instead, average $\ln \_z$ values are notably smaller for commercial banks; this concurs with great part of the literature (e.g., Hesse and Čihák 2007; Chiaramonte et al. 2015; Köhler 2015). The ranking holds for both periods, hinting that the publication of the new Accord did not alter the banks' BMs-risk nexus.

To further examine $z$-scores we report its evolution across countries and over time (Figs. 1 and 2). Figure 1 reports country averages of $\ln z$ over 2000-2014. Darker colours indicate higher values of $\ln \_z$. Spatial clustering shows up: proximity contagion seems to spread banks' negative/positive performance, Eastern countries being the riskiest. Thus, our model should have country-specific control variables to minimize country-level unobserved heterogeneity. Focusing on the GIPSI (Greece, 
Table 2 Ln $z$ by business model and its decomposition

\begin{tabular}{llllllllll}
\hline & Ln_z & \multicolumn{4}{c}{$C A R(\%)$} & \multicolumn{3}{l}{ ROAA (\%) } & \multicolumn{3}{l}{ SDROAA (\%) } \\
\hline & $\mathbf{2 0 0 0}-$ & $\mathbf{2 0 1 1}-$ & $\mathbf{2 0 0 0}-$ & $\mathbf{2 0 1 1}-$ & $\mathbf{2 0 0 0}-$ & $\mathbf{2 0 1 1}-$ & $\mathbf{2 0 0 0}-$ & $\mathbf{2 0 1 1}-$ \\
& $\mathbf{2 0 1 0}$ & $\mathbf{2 0 1 4}$ & $\mathbf{2 0 1 0}$ & $\mathbf{2 0 1 4}$ & $\mathbf{2 0 1 0}$ & $\mathbf{2 0 1 4}$ & $\mathbf{2 0 1 0}$ & $\mathbf{2 0 1 4}$ \\
Commercial banks & 2.602 & 2.651 & 12.143 & 12.722 & 0.683 & 0.266 & 1.140 & 0.823 \\
Bank holdings \& holding & 2.329 & 2.353 & 24.465 & 25.168 & 1.566 & 0.737 & 2.715 & 1.599 \\
companies & & & & & & & & \\
Cooperative banks & 3.783 & 3.858 & 7.800 & 9.037 & 0.399 & 0.290 & 0.271 & 0.177 \\
Investment banks & 2.397 & 2.601 & 21.989 & 25.126 & 1.547 & 0.909 & 3.042 & 1.715 \\
Real estate \& mortgage banks & 3.030 & 2.926 & 9.712 & 11.192 & 0.477 & 0.212 & 0.618 & 0.667 \\
Savings banks & 4.031 & 4.394 & 6.174 & 9.030 & 0.260 & 0.218 & 0.210 & 0.139 \\
\hline
\end{tabular}

This table shows the natural logarithm of the $z$-score $(\ln z)$ and its components $(C A R, R O A A$ and $S D R O A A)$ by business model for the Eurozone sample banks in the two subperiods (2000-2010 and 2011-2014)

Source: Bankscope
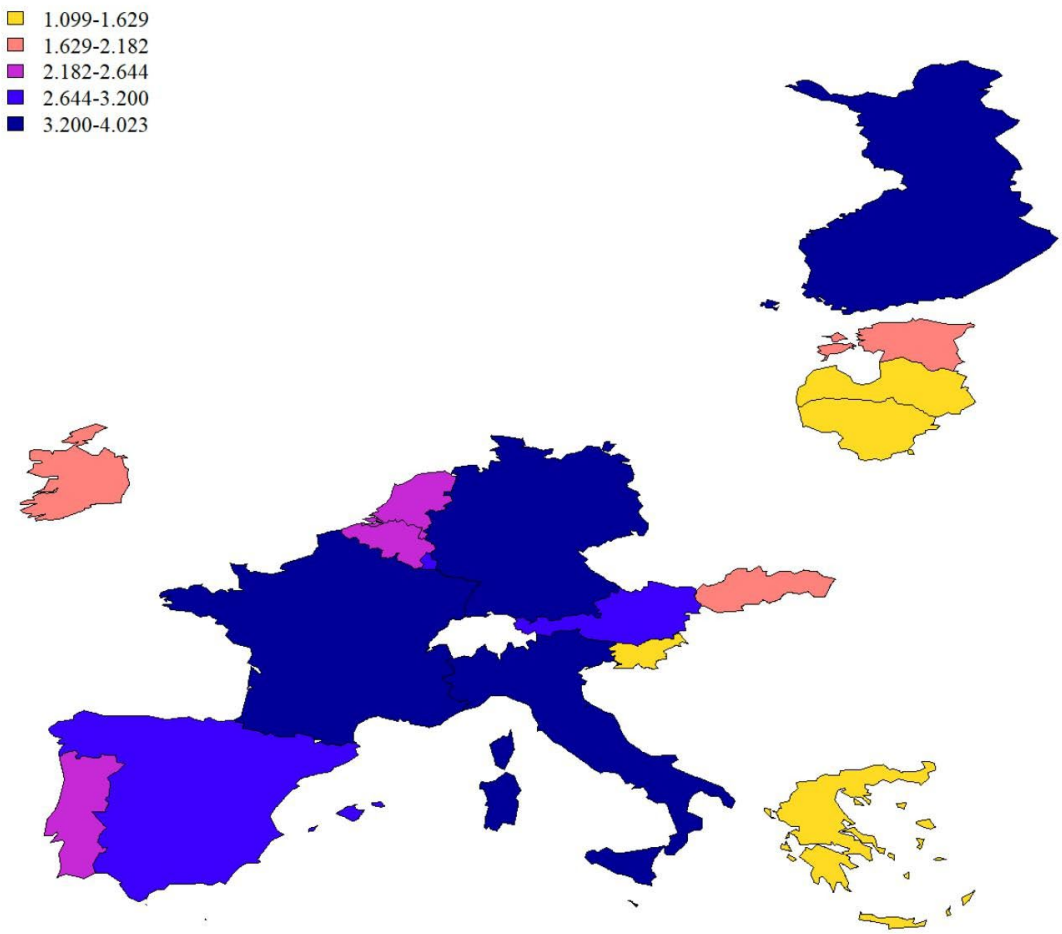

Fig. 1 International comparison of $\ln \_$: 2000-2014. This figure shows the ranges of the Eurozone country averages during the years $2000-2014$ of the natural logarithm of the $z$-score $\left(\ln \_z\right)$. Different colours indicate different quintiles of $\ln \_$, with higher values being darker. Source: Bankscope

Ireland, Portugal, Spain, and Italy) crisis countries, Italy emerges as the most stable (darkest) country. Finally, Fig. 2 displays the $z$-score distribution by country/year; 


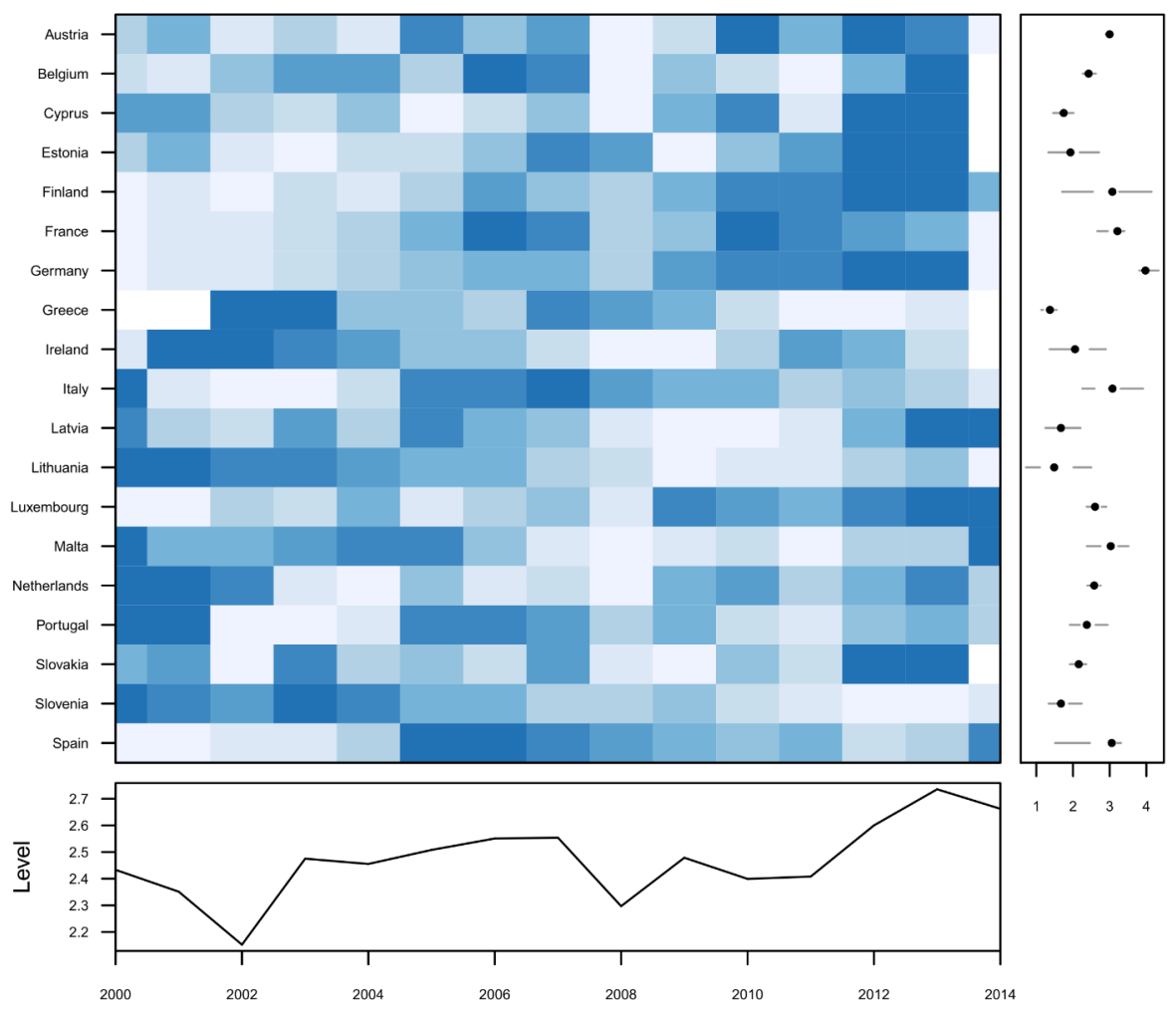

Fig. 2 Ln $z$ distribution by country and year. This figure shows the distribution of the natural logarithm of the $z$-score $\left(\ln \_z_{-}\right)$for each Eurozone sample country and every year of the whole sample period. Darker shading represents a higher $\ln \_$; the data are discretized along level categories of $\ln \_$. On the right, boxplots for each country and, on the bottom, the time series of median values by year are produced. Source: Bankscope

again, darker shading indicates higher $\ln \_z$. As shown, z-score improves over time; the worst median values refer to the years 2002 and 2008. This trend is consistent with the overall evidence in ECB (2015), which underlines Eurozone financial institutions continuously strengthening their balance sheets and building up resilience to adverse shocks. In unison, European banks still face various challenges, from weak economic growth prospects to more stringent regulatory constraints. These factors emphasize the financial stability issue and its key role in policymakers' priorities. Looking at individual cases, we find average stability steadily improving in some countries - e.g., Austria, Finland and Germany. Instead, the positions of Greece and Ireland are deteriorating. Italy and Spain reached their maximum stability in the intermediate years (2005-2007).

\subsection{Explanatory variables}

Explanatory variables include the Basel 3 requirements: capital requirement (CR), leverage ratio (LR), liquidity coverage ratio (LCR), and net stable funding ratio 
Table 3 Explanatory variables and expected signs

\begin{tabular}{|c|c|c|c|c|}
\hline Variable & Measure & Symbol & $\begin{array}{l}\text { Ex- } \\
\text { pect- } \\
\text { ed } \\
\text { sign }\end{array}$ & Source \\
\hline \multicolumn{5}{|l|}{ Basel 3 variables } \\
\hline Capital requirement & Common equity to risk-weighted assets & $\mathrm{CR}$ & + & Bankscope \\
\hline Leverage ratio & $\begin{array}{l}\text { Tangible common equity to tangible } \\
\text { assets }\end{array}$ & LR & + & Bankscope \\
\hline Liquidity coverage ratio & $\begin{array}{l}\text { Cash and due from banks and govern- } \\
\text { ment securities to total deposits, money } \\
\text { market and short-term funding }\end{array}$ & LCR & $+/-$ & Bankscope \\
\hline Net stable funding ratio & $\begin{array}{l}\text { Available stable funding to required } \\
\text { stable funding }\end{array}$ & NSFR & + & Bankscope \\
\hline \multicolumn{5}{|l|}{ Bank-level variables } \\
\hline Business model & $\begin{array}{l}\text { commercial banks } \\
\text { bank holdings and holding companies } \\
\text { cooperative banks } \\
\text { investment banks } \\
\text { real estate and mortgage banks } \\
\text { savings banks }\end{array}$ & $\begin{array}{l}B M_{m} \\
B M_{h} \\
B M_{o} \\
B M_{i} \\
B M_{r} \\
B M_{s}\end{array}$ & & Bankscope \\
\hline Size & Natural logarithm of total assets & SIZE & $+/-$ & Bankscope \\
\hline Efficiency & Cost-income ratio & CIR & $+/-$ & Bankscope \\
\hline Credit risk & Loans loss provisions to gross loans & LLP & - & Bankscope \\
\hline \multicolumn{5}{|l|}{ Country-level variables } \\
\hline Gross domestic product & $\begin{array}{l}\text { Annual real gross domestic product } \\
\text { growth rate }\end{array}$ & GDPGR & $+/-$ & $\begin{array}{l}\text { The World } \\
\text { Bank }\end{array}$ \\
\hline $\begin{array}{l}\text { Concentration in the banking } \\
\text { system }\end{array}$ & $\begin{array}{l}\text { Share of assets held by the three largest } \\
\text { banks to total banking system assets }\end{array}$ & CONC & $+/-$ & Bankscope \\
\hline Central government debt & Central government debt to GDP ratio & CGD & - & $\begin{array}{l}\text { The World } \\
\text { Bank }\end{array}$ \\
\hline Inflation & Annual change in consumer price index & CPI & - & $\begin{array}{l}\text { The World } \\
\text { Bank }\end{array}$ \\
\hline
\end{tabular}

This table shows all the explanatory variables, the way in which they are measured and named and the expected sign of their link with the $z$-score, as well as the sources utilized to collect and determine them

Source: Bankscope

(NSFR). The Basel 3 framework could boost financial stability, although the literature highlights an uncertain relationship of LCR with stability (see Sect. 4.2.1). Our set of explanatory variables also includes some bank-specific characteristics (size, efficiency, and credit risk) and country-specific controls (GDP, concentration in the banking system, central government debt, and inflation). All variables - except country-level ones - are winsorized at $0.5 \%$ to discard outliers.

Table 3 describes all explanatory variables, how they are measured and named and the expected sign of their link with $\ln \_z$, as well as the sources used to collect and determine them. 


\subsubsection{Basel 3 variables}

The first Basel 3 measure that we examine is the capital requirement (CR), precisely the capital buffer, given by common equity to risk-weighted assets. We view CR as a proxy for higher and improved quality of capital (common equity) banks are required to hold under the new rules. Hence, the requirement to increase the capital ratio beyond the $4.5 \%$ minimum threshold closely relates to the opportunity to ensure banks' stability. CR allows banks to absorb financial consequences due to unexpected negative asset returns (e.g., Shim 2013). It may act as a cushion against costs from capital shocks and difficulties in raising new funds, as well as from supervisory intervention in case regulatory capital ratios touch or fall below the $4.5 \%$ threshold (Marcus 1984; Furfine 2001).

- On these grounds, we expect a positive relationship between CR and $\ln \_z$.

As a supplement and complement to the Basel risk-based capital framework, the leverage ratio (LR), a simple, transparent and independent risk measure (Haldane and Madouros 2012), aims to reduce risk exposure in the banking sector, thus contributing to avoid sudden deleveraging so harmful to the financial system and the economy, and to protect against model risk and measurement error. We measure the Basel 3 LR as the tangible common equity/tangible assets ratio (Ayadi and De Groen 2014; D'Apice et al. 2016). This LR proxy is particularly relevant to us, since, as Ayadi and De Groen (2014) find, it is statistically distinct for all the investigated banks' BMs (investment, wholesale, diversified-retail and focused-retail banks). One could argue that CR and LR measure the same dimension. However, they are only (slightly) positively correlated: their correlation is 0.15 in our sample. Thus, they are not collinear and have autonomous variability.

We expect a bank's stability to be positively related to its LR, thanks to lower exposure (implying higher equity ratios) to debt overhang problems. As a non-riskweighted-based measure, LR aims to complement and provide a backstop for the risk approach of Basel 2: while the risk-weighted capital ratio indicates a bank's capacity to face potential losses, LR gives the maximum loss the equity can absorb. In light of this, some considerations suggest LR may help banks' stability. Firstly, LR is less prone to regulatory arbitrage than risk-weighted capital ratios (Ferri and Pesic 2017) and, especially when the risk of crisis is high, LR seems to more reliably predict bank distress than the latter ratio (Mariathasan and Merrouche 2014). LR may also limit the probability of bank runs. During economic booms, when the probabilities of loan default are low, a floor on leverage allows curbing the risk of a bank run (Dermine 2015). Moreover, Brei and Gambacorta (2014) show that LR is less procyclical than risk-weighted capital ratios. By limiting the effects of the risk-weighted compression during booms, it offsets the build-up of systemic risk; hence, it represents a tighter requirement during boom periods and a looser one in busts.

- Therefore, we expect a positive relationship between LR and ln_z. 
Basel 3 features two liquidity risk standards: liquidity coverage ratio (LCR) — ratio of stock of high-quality liquid assets to net cash outflows over a 30-day horizon - and net stable funding ratio (NSFR) - ratio of available stable funding (ASF) to required stable funding (RSF). Computing both standards is critical in empirical research given the gap, in terms of format and granularity, between existing public data and the information needed to calculate these two Basel 3 ratios.

Estimating LCR requires details of the composition and duration of liquid assets and 30-day liabilities, which are unavailable in our database. Accordingly, we do not attempt to calculate the Basel 3 LCR (BCBS 2013) but use one of the many liquidity ratio proxies in the literature. The most common measures are: liquid assets to total assets (Bourke 1989; Molyneux and Thornton 1992; Barth et al. 2003; DemirgüçKunt et al. 2003; Shen and Chen 2014), liquid assets to deposits (Shen et al. 2001) and liquid assets to customer and short-term funding (Kosmidou et al. 2005; Poghosyan and Čihák 2009; Bonfim and Kim 2012). Inspired by this last quantitative measure, our LCR proxy consists of liquid assets (cash and due from banks and government securities) as a percentage of total deposits, money market and short-term funding.

For most studies, liquidity buffers strengthen bank stability and curb the probability of negative externalities in the financial system, but there are opposite views. On one hand, Kowalik (2013) and Shen and Chen (2014) highlight that liquidity buffers cut the probability of bank runs. Van den End and Kruidhof (2013) show that they hamper fire sales, deleveraging and the restriction of credit. Allen and Gale (2004), Farhi et al. (2009), Acharya et al. (2011), Tirole (2011) and Vives (2011) point out that liquidity buffers alleviate the maturity gap between assets and liabilities. Bonfim and Kim (2012) show that they mitigate refinancing risk and Köhler (2015) finds that liquid assets buffer liquidity shocks, making liquid banks less risky. On the other hand, Wagner (2007) shows that, paradoxically, holding more liquid buffers may induce banks to take more risks.

- Thus, the sign of the relationship between LCR and ln_z cannot be established a priori.

In turn, NSFR is a ratio of available (ASF) to required stable funding (RSF). ASF is a weighted sum of funding sources where weights depend on the relative stability of a bank's funding sources. Similarly, RSF is a weighted sum of uses of funding sources with weights assigned to various types of assets according to their residual maturity or liquidity value (BCBS 2014).

We construct NSFR estimates using publicly available data, following several recent studies (Ötker-Robe and Pazarbasioglu 2010; Bonfim and Kim 2012; Yan et al. 2012; Distinguin et al. 2013; King 2013; Scalia et al. 2013; Dietrich et al. 2014; Gobat et al. 2014; Hong et al. 2014; Vázquez and Federico 2015;). So, we derive the NSFR time series comparably, calculating a good approximation of the Basel 3 indicator. Obviously, since the data available in Bankscope do not allow to accurately classify all the NSFR components, our measure is also a simplified version of the BCBS (2014) guidelines, based on simplified assumptions on the ASF and RSF weights. As in Gobat et al. (2014), our baseline hypotheses treat loans rather conser- 
Table 4 ASF and RSF components and associated factors

This table shows the items entering our proxy for the Basel 3 NSFR and the relative ASF and RSF factors

Source: Bankscope

\begin{tabular}{ll}
\hline Available Stable Funding & \\
Components & $\begin{array}{l}A S F \\
\text { factors }\end{array}$ \\
Customer Deposits_Current & $90 \%$ \\
Customer Deposits_-Savings & $95 \%$ \\
Customer Deposits_-Term & $95 \%$ \\
Deposits from Banks & $0 \%$ \\
Total Long Term Funding & $100 \%$ \\
Non-interest Bearing Liabilities & $0 \%$ \\
Hybrid Capital & $100 \%$ \\
Total Equity & $100 \%$ \\
Required Stable Funding & \\
Components & $R S F$ \\
& factors \\
Loans (Residential Mortgage Loans+Consumer/Retail & $85 \%$ \\
Loans+Corporate \& Commercial Loans) & \\
Loans and Advances to Banks & $0 \%$ \\
Government Securities & $5 \%$ \\
At-equity Investments in Associates & $100 \%$ \\
Total Securities_-Government Securities-At-equity & $50 \%$ \\
Investments in Associates & \\
Other Earning Assets & $100 \%$ \\
Cash and Due from Banks & $0 \%$ \\
Fixed Assets & $100 \%$ \\
Intangibles (Goodwill and Other Intangibles) & $100 \%$ \\
Other non-earning Assets & $100 \%$ \\
Off Balance Sheet Items & \\
Guarantees & $5 \%$ \\
Committed Credit Lines & $5 \%$ \\
\hline
\end{tabular}

vatively (all loans have maturity above 1 year), rank government securities as level 1 assets, and apply to other securities a 50\% RSF weight.

Some authors study the nexus between NSFR and soundness of the financial sector. Vázquez and Federico (2015) find a higher default probability for banks with weaker structural liquidity (i.e., lower NSFR). Also, Yan et al. (2012) report that NSFR would curb expected crisis costs. López-Espinosa et al. (2012) identify shortterm wholesale funding as the most relevant systemic factor, supporting BCBS' decision to introduce NSFR. Giordana and Schumacher (2012) find that z-scores of Luxembourg's banks strongly depend on measures of time structure and funding stability.

- Overall, we expect a positive relationship between NSFR and ln_z.

Table 4 provides details on the items entering our estimates and the relative ASF and RSF factors.

Some variables used to compute the Basel 3 indicators, presented in this subsection, have several missing values. To widen the sample for our inferences, we 
replaced these missing values with the median values of each variable by country and year, before computing the Basel 3 indicators.

\subsubsection{Control variables}

Our set of control variables includes some bank-specific characteristics and countryspecific controls.

Among bank-level variables, we consider bank size, recognized as an important driver of banks' risk, proxied by total assets (De Nicoló 2000; Bhagat et al. 2015). To better approximate a normal distribution, we take the natural logarithm of total assets (SIZE). We also control for a bank's efficiency (among others, Williams 2004; Fiordelisi et al. 2010), measured as non-interest expense to gross revenues (costincome ratio, CIR). Finally, we use the loan loss provisions/gross loans ratio (LLP) as a proxy for the riskiness of loan portfolios (e.g., Beck et al. 2010).

To control for country-specific risk factors, we use four macroeconomic variables.

The first one is the annual growth rate of real GDP (GDPGR) (e.g., Conrad et al. 2009). Aimed to capture banking sector competition, the second variable is the degree of concentration in the banking industry (CONC), taken as the assets share held by the three largest banks in the total banking system (Beck et al. 2006; Van Ewijk and Arnold 2013; Hryckiewicz 2014). Next, the central government debt to GDP ratio (CGD) impacts bank stability (e.g., Acharya and Steffen 2013). Finally, we measure the impact of inflation on banks' risk with the annual change in the consumer price index (CPI) (Arpa et al. 2001; Uhde and Heimeshoff 2009).

Table 5 reports summary statistics of all the variables relating to our sample banks for the whole period and the two subperiods. Values do not change dramatically over time, except for CR, LCR and especially NSFR. The mean value of the latter indeed broadly rises (more than quadrupling) from the first subperiod to the period subsequent to the finalization of the Basel 3 rules (2011-2014). Among the country-level variables, it is worth noting that GDPGR highlights the economic slowdown during the crisis years (2011-2014).

\section{Empirical methodology}

To investigate empirically the impact of banks' business models (BMs) on the relation between Basel 3 indices and $\ln \_z$ on a panel data set, we use the methodology by Blundell and Bond (1998). Building on the work of Arellano and Bover (1995), they develop a system estimator of linear dynamic panel data models that uses additional moment conditions. All the estimated specifications have first-differenced residuals that are insignificantly autocorrelated from the second-order onwards (ArellanoBond test). First-order autocorrelation is inevitable in differenced residuals, but it is not a problem.

The dynamic specification of our models accounts for the potential residual endogeneity that can bias the results of static specifications. We fit our estimates with the two-step GMM system estimator (Blundell and Bond 1998) and use Windmeijer's (2005) finite-sample correction for standard errors. All specifications include year 
Table 5 Summary statistics of the $\ln \_z$ and the explanatory variables

\begin{tabular}{|c|c|c|c|c|c|c|c|c|}
\hline Variable & Mean & & & Standar & Deviati & & Minimum & Maximum \\
\hline & $\begin{array}{l}2000- \\
2014\end{array}$ & $\begin{array}{l}2000- \\
2010\end{array}$ & $\begin{array}{l}2011- \\
2014\end{array}$ & $\begin{array}{l}2000- \\
2014\end{array}$ & $\begin{array}{l}2000- \\
2010\end{array}$ & $\begin{array}{l}2011- \\
2014\end{array}$ & $2000-2014$ & 2000-2014 \\
\hline $\ln \_z$ & 3.561 & 3.534 & 3.633 & 1.174 & 1.115 & 1.323 & -1.451 & 6.524 \\
\hline$C R$ & 0.070 & 0.036 & 0.162 & 0.172 & 0.114 & 0.252 & 0.000 & 1.643 \\
\hline$L R$ & 0.092 & 0.088 & 0.104 & 0.111 & 0.107 & 0.118 & 0.004 & 0.936 \\
\hline$L C R$ & 0.314 & 0.285 & 0.403 & 1.745 & 1.629 & 2.067 & 0.000 & 20.693 \\
\hline NSFR & 3.087 & 1.593 & 8.047 & 13.174 & 5.502 & 24.843 & -16.090 & 116.673 \\
\hline$B M_{m}$ & 0.217 & & & 0.412 & & & 0 & 1 \\
\hline$B M_{h}$ & 0.025 & & & 0.157 & & & 0 & 1 \\
\hline$B M_{o}$ & 0.476 & & & 0.499 & & & 0 & 1 \\
\hline$B M_{i}$ & 0.038 & & & 0.191 & & & 0 & 1 \\
\hline$B M_{r}$ & 0.033 & & & 0.179 & & & 0 & 1 \\
\hline$B M_{s}$ & 0.211 & & & 0.408 & & & 0 & 1 \\
\hline$S I Z E$ & 13.506 & 13.445 & 13.672 & 1.822 & 1.782 & 1.918 & 9.240 & 20.050 \\
\hline CIR & 0.681 & 0.682 & 0.678 & 0.184 & 0.180 & 0.197 & 0.083 & 1.825 \\
\hline$L L P$ & 0.009 & 0.010 & 0.006 & 0.027 & 0.027 & 0.028 & -0.049 & 0.333 \\
\hline$G D P G R$ & 0.012 & 0.014 & 0.007 & 0.026 & 0.027 & 0.019 & -0.180 & 0.122 \\
\hline CONC & 0.532 & 0.511 & 0.590 & 0.212 & 0.202 & 0.229 & 0.212 & 1.000 \\
\hline$C G D$ & 0.615 & 0.595 & 0.722 & 0.293 & 0.293 & 0.273 & 0.037 & 1.935 \\
\hline$C P I$ & 0.020 & 0.019 & 0.021 & 0.010 & 0.011 & 0.007 & -0.045 & 0.154 \\
\hline
\end{tabular}

This table shows the summary statistics of the natural logarithm of the $z$-score ( $\left.l n \_z\right)$ and of the explanatory variables for the eurozone sample banks during the whole sample period (2000-2014) and the two subperiods (2000-2010 and 2011-2014). The business models are: $B M_{m}=$ coommercial banks; $B M_{h}=$ bank holdings and holding companies; $B M_{o}=$ cooperative banks; $B M_{i}=$ investment banks; $B M_{\mathrm{r}}=$ real estate and mortgage banks; $B M_{\mathrm{s}}=$ savings banks

Source: Bankscope

dummies and a constant. We also include the first lag of $\ln \_$. This dynamic specification allows us to consider the degree of a bank's risk persistence connected to some factors, such as competition, banks' risky customer relationships, intertemporal risk smoothing and regulation (Delis and Kouretas 2011). Given the coherence among the signs of the estimated coefficients along many specifications that we tested (some presented and others available from the authors upon request), our results receive sound empirical support.

Tables 6 and 7 present the results of different dynamic panel regression models. The base models control for a large set of relevant predictors suggested in the literature, as discussed above, and differ only in the estimation sample: the years 2000-2010 and the years 2011-2014. These subsamples may detect possible structural changes in the parameters across the two subperiods. Two further models with interactions, estimated on the two sample periods, follow. The interactions of the banks' BMs with the Basel 3 variables serve to identify the effect that is the main object of our investigation: whether and how the Basel 3 variables' effect on banks' $z$-score differs among banks working under different BMs. The estimated coefficients represent the variation in the effects of each category with respect to commercial banks, the omitted category. Finally, tests on linear combinations (composite effects) of the coefficients of the Basel 3 variables by BM allow appraising the different impacts on the stabil- 
ity of banks working under different BMs when a policy based on an increase of one standard deviation of the Basel 3 variables is implemented (Table 8).

\section{Empirical results}

Table 6 states the estimation results on the dependent variable, $\ln \_$. The two models cover the two sample-split subperiods (2000-2010 vs. 2011-2014), with 21,106 and 5,699 observations, respectively.

Significant year dummies in Table 6 models, pointing to common movements in $z$-score across time, suggest that all banks share some degree of business risk. In addition, our results confirm that banks' risk taking is highly persistent, as testified by the high and significantly positive coefficient for the lag of $\ln z$. This suggests that to derive consistent estimates one must control for dynamics in bank risk taking.

About Basel 3 variables, Table 6 suggests that CR favours banks' stability only in the pre-Basel 3 rules period, which could be interpreted as consistent with the view that procyclicality in Basel 2 did not extend to Basel 3 (Repullo and Suarez 2013). Stability is mainly explained by LR. For this requirement, our results are consistent with the literature: in fact, LR has a positive and significant (at the $1 \%$ level) effect on banks' stability and this holds in both time periods. Among the liquidity indicators, LCR has a negative coefficient scarcely significant. This result validates the hypothesis that illiquid banks are less risky, since holding more liquid buffers may induce banks to take more risk (Wagner 2007). Finally, NSFR has a positive but not significant coefficient in both time periods.

All bank-level variables strongly affect banks' stability. However, SIZE does not exert a coherent effect along the two time periods. The coefficient of the cost-income ratio, our efficiency measure, is negative and highly significant: an increase in the CIR (lower efficiency) damages bank stability, probably because less-efficient banks tend to undertake more risk (Kwan and Eisenbeis 1997; Williams 2004; Fiordelisi et al. 2010). As expected, the last bank-level variable proxying for loan portfolio risk (loans loss provisions/gross loans) has a negative and significant coefficient: lower asset quality links to higher risk (e.g., Stiroh 2006; Van Oordt and Zhou 2014).

Turning to country-level variables, GDPGR has a positive coefficient, suggesting that banks' credit risk drops during economic booms (Kashyap et al. 1993; Conrad et al. 2009). Instead, the degree of concentration in the banking industry has a negative and significant coefficient. This supports the hypothesis that more concentrated banking markets heighten financing costs, so companies tend to enter debt only for highrisk projects, raising the credit risk borne by banks (Boyd and De Nicolò 2005). The central government debt to GDP ratio seems to have negative but irrelevant effect in subperiod 2000-2010. Instead, its effect is positive and significant in subperiod 2011-2014 featuring the euro sovereign crisis. This would seem at odds with the sovereign-bank doom loop view by Brunnermeier et al. (2016) where high public debt may translate into large holdings of public sector securities by domestic banks and that would raise the credit risk of both the sovereign and the banking sector, via a diabolic loop that increases the probability of twin crises. However, this switch in sign and significance of public debt could be in line with more recent reassessments of 
Table 6 Dynamic panel regressions-base models
Two-step GMM system estimation (Blundell and Bond 1998): the dependent variable is the natural logarithm of the $z$-score $\left(\ln \_z\right)$, which measures banks' stability; Arellano-

Bond 2nd order test on residuals not significant (1.38, 0.63); Windmeijer's (2005) finite-sample corrected-robust standard errors in parentheses. All the model specifications include year dummies and a constant. The superscripts ${ }^{* * *}$, ** and ${ }^{*}$ stand for coefficients that are statistically different from zero at the $1 \%, 5 \%$ and $10 \%$ levels, respectively. Test of differences reports whether the coefficients in the two subperiods significantly differ Source: Bankscope

\begin{tabular}{|c|c|c|c|}
\hline & $\begin{array}{l}\text { Years } \\
2000-2010\end{array}$ & $\begin{array}{l}\text { Years } \\
2011-2014\end{array}$ & $\begin{array}{l}\text { Test of } \\
\text { differences }\end{array}$ \\
\hline & $\begin{array}{l}\text { Coefficient } \\
\text { (WC-Robust } \\
\text { st. err.) }\end{array}$ & $\begin{array}{l}\text { Coefficient } \\
\text { (WC-Robust } \\
\text { st. err.) }\end{array}$ & \\
\hline l.z-score (log of) & $\begin{array}{l}0.451^{* * *} \\
(0.0530)\end{array}$ & $\begin{array}{l}0.914^{* * *} \\
(0.0588)\end{array}$ & \\
\hline \multicolumn{4}{|l|}{ Basel 3 variables } \\
\hline$C R$ & $\begin{array}{l}0.0977^{* *} \\
(0.0386)\end{array}$ & $\begin{array}{l}-0.0734^{* * *} \\
(0.0265)\end{array}$ & $* * *$ \\
\hline$L R$ & $\begin{array}{l}4.856^{* * *} \\
(0.320)\end{array}$ & $\begin{array}{l}7.388^{* * *} \\
(0.645)\end{array}$ & \\
\hline$L C R$ & $\begin{array}{l}-0.0129^{*} \\
(0.00670)\end{array}$ & $\begin{array}{l}-0.00573 \\
(0.00623)\end{array}$ & $* *$ \\
\hline$N S F R$ & $\begin{array}{l}0.000367 \\
(0.000399)\end{array}$ & $\begin{array}{l}0.000287 \\
(0.000322)\end{array}$ & \\
\hline \multicolumn{4}{|c|}{ Bank-level variables } \\
\hline SIZE & $\begin{array}{l}-0.216^{* * *} \\
(0.0292)\end{array}$ & $\begin{array}{l}0.149^{* *} \\
(0.0748)\end{array}$ & \\
\hline CIR & $\begin{array}{l}-0.482^{* * *} \\
(0.0468)\end{array}$ & $\begin{array}{l}-0.281^{* *} \\
(0.126)\end{array}$ & \\
\hline$L L P$ & $\begin{array}{l}-1.996^{* * *} \\
(0.395)\end{array}$ & $\begin{array}{l}-4.001^{* * *} \\
(0.795)\end{array}$ & $* * *$ \\
\hline \multicolumn{4}{|c|}{ Country-level variables } \\
\hline$G D P G R$ & $\begin{array}{l}1.052^{* * *} \\
(0.381)\end{array}$ & $\begin{array}{l}0.707 \\
(1.131)\end{array}$ & $* *$ \\
\hline CONC & $\begin{array}{l}-0.128^{*} \\
(0.0717)\end{array}$ & $\begin{array}{l}-2.036^{* * *} \\
(0.482)\end{array}$ & \\
\hline$C G D$ & $\begin{array}{l}-0.213 \\
(0.132)\end{array}$ & $\begin{array}{l}0.253^{*} \\
(0.152)\end{array}$ & $* * *$ \\
\hline$C P I$ & $\begin{array}{l}0.477 \\
(0.584)\end{array}$ & $\begin{array}{l}-2.784^{* * *} \\
(0.674)\end{array}$ & \\
\hline Observations & 21,106 & 5,699 & \\
\hline Groups & 2,984 & 2,945 & \\
\hline Instruments & 87 & 39 & \\
\hline Regression $\chi^{2}$ & $6,243^{* * *}$ & $2,700^{* * *}$ & \\
\hline
\end{tabular}

larger fiscal multipliers (Blanchard and Leigh 2013; Dallari and Ribba 2020; Dosi et al. 2015) and with the growing evidence that these multipliers tend to be smaller during economic booms and larger during recessions (Afonso et al. 2018). Finally, inflation shows a negative and significant impact only in subperiod 2011-2014. While this effect seems consistent with the related literature (Arpa et al. 2001; Baboucek and Jancar 2005; Uhde and Heimeshoff 2009; Demirgüç-Kunt and Detragiache 2011), one might question whether that can be stretched to the Eurozone situation featuring a risk of deflation at that time. Upon a closer look we can see that core inflation never dipped below zero in the Eurozone average and even for the GIPSI countries, facing sovereign debt tensions, it only did so marginally $(-0.07 \%)$ in 2014 , while the GIPSI continued to have higher inflation than the Eurozone average still in 2011 and 2012. Thus, higher inflation in the peripheral countries could still be denting export competitiveness, possibly damaging the macroeconomy and the performance of the banking sector (Johnston and Regan 2016). 
In non reported results we checkecd also for holdings of domestic and foreign general government debt, non-performing loans to total loans ratio, general government debt, not central government debt and interbank money market rate (we thank an anonymous reviewer for suggesting additional controls to check the robustness of our results). The results were not substantially changed by the inclusion of these additional controls at the expenses of a reduction of the observations.

The second step of the analysis is the most important and novel part of our work. The dynamic panel regressions of Table 7 study banks' stability by interacting Basel 3 variables and banks' BMs.

Also in Table 7, the two models are estimated over the two subperiods (2000-2010 and 2011-2014).

Our results found many differences in the coefficients of the Basel 3 variableseven opposite signs - across different BMs. This supports our view that the current framework is a "one-size-fits-all" regulatory paradigm, also in accordance with other studies (e.g., Ötker-Robe and Pazarbasioglu 2010; Dietrich et al. 2014; EBA 2014; Vázquez and Federico 2015; Khafagy 2018).

Finally, we quantify the overall impact that each BM exerts on the effects of Basel 3 requirements on banks' stability. To accomplish this, we use the estimated coefficients of the Basel 3 variables in Table 7 to compute, for each BM, the composite effect of a contemporaneous increase of one standard deviation $(S D)$ in the Basel 3 variables. Thus, the composite effect (CE) for $B M_{k}$ (BM of type $k=m, h, o, i, r, s$ ) is the linear combination obtained as follows:

$\mathrm{CE}=S D_{C R} \bullet\left(\beta_{C R}+\beta_{C R * B M_{k}}\right)+S D_{L R} \bullet\left(\beta_{L R}+\beta_{L R * B M_{k}}\right)+S D_{L C R} \bullet\left(\beta_{L C R}+\beta_{L C R * B M_{k}}\right)+S D_{N S F R} \bullet\left(\beta_{N S F R}+\beta_{N S F R * B M_{k}}\right)$

where $S D_{j}$ is an increase equal to one standard deviation in the estimation sample of variable $j(=C R, L R, L C R, N S F R)$; and $\beta_{j}$ and $\beta_{j * B M_{k}}$ are the estimated coefficients presented in Table 7 . Note that for the reference category $m$, commercial banks, all the coefficients $\beta_{j * B M_{k}}$ are equal to zero.

Table 8 reports the results. For each period, $\Delta$ stands for the difference between the $\mathrm{CE}$ of each line and the $\mathrm{CE}$ of the first line, which is relative to the benchmark category commercial banks. In other words, $\Delta$ is equal to the linear combination of the increases of the Basel 3 variables with only the coefficients of the interaction terms:

$$
\Delta=S D_{C R} \bullet\left(\beta_{C R * B M_{k}}\right)+S D_{L R} \bullet\left(\beta_{L R * B M_{k}}\right)+S D_{L C R} \bullet\left(\beta_{L C R * B M_{k}}\right)+S D_{N S F R} \bullet\left(\beta_{N S F R * B M_{k}}\right)
$$

All effects are tested to check whether they significantly differ from zero. $\Delta$ significantly positive means that the policy based on increases of one standard deviation of the Basel 3 variables has a larger positive effect on banks' stability for $B M_{k}$ vis-à-vis the benchmark.

Table 8 shows that cooperative and savings banks are the most affected by the Basel 3 rules (see the $\Delta$ columns). This suggests that more focus on traditional activity, rather than strategies of diversification, could represent a positive driver of stability when reform measures based on Basel 3 are introduced. 


\section{Robustness checks}

We perform several robustness checks. ${ }^{2}$ First, we estimate the models reported in Tables 6 and 7 using an alternative LR: tier 1 capital to total assets (Altunbas et al. 2011; Brei and Gambacorta 2014) rather than tangible common equity to tangible assets. Our conclusions remain substantially unchanged. In particular, LR has a positive and significant impact on banks' stability.

Second, we should acknowledge a potential criticism regarding endogeneity. LR, LCR and NSFR used in our dynamic panel regressions may not be strictly exogenous: by construction, shocks today in $\ln z$ might affect future values of these Basel 3 requirements. Thus, as a robustness check, we run regressions treating these variables as predetermined. Lags of LR, LCR and NSFR are used as instruments for these predetermined variables. The results, however, do not change significantly. The relevant variables continue to show the same sign and significance. If an endogeneity problem afflicts our estimations, the possible bias does not reverse our results. Once again, LR contributes to banks' stability: it always has a positive and significant coefficient. LCR and NSFR do not result significant.

Third, we test the regressions using an alternative LCR proxy: liquid assets to total assets (Bourke 1989; Molyneux and Thornton 1992; Barth et al. 2003; Demirgüç-Kunt et al. 2003; Shen and Chen 2014) rather than liquid assets to total deposits, money market and short-term funding. The findings are in line with the models reported above : this liquidity indicator is not significant.

Finally, we repeat our estimates excluding the country with almost half of the banks of our sample (Germany, see Table 1). Most results still hold (in particular, LR has a positive and significant coefficient in all the periods). We attain the same results considering only Germany.

\section{Conclusions}

The global financial and economic crisis urged regulators, supervisors and policymakers to assess which drivers can effectively avoid excess risk taking and ensure banks' stability. On one hand, regulatory reform in Europe homogeneously applies Basel 3-CRD IV-CRR to each bank. On the other hand, however, it is increasingly accepted that banks' business models (BMs) can play a key role too. Against this background, we tackled two main research questions on a large sample of Eurozone banks classified into six different BMs over 2000-2014 (divided in two subsamples 2000-2010 and 2011-2014). First, while Basel 3 is multifaceted, featuring four chief regulatory innovations - capital buffer (CR), leverage ratio (LR), liquidity coverage ratio (LCR), and net stable funding ratio (NSFR) - , most studies have focused on just one or two of the four innovations, not venturing to capture the overall thrust of Basel 3 on banks' risk taking. Thus, our first task was to offer a comprehensive analy-

\footnotetext{
${ }^{2}$ The complete set of results of the model specifications that we mention in the following is omitted for brevity but is available from the authors upon request.
} 


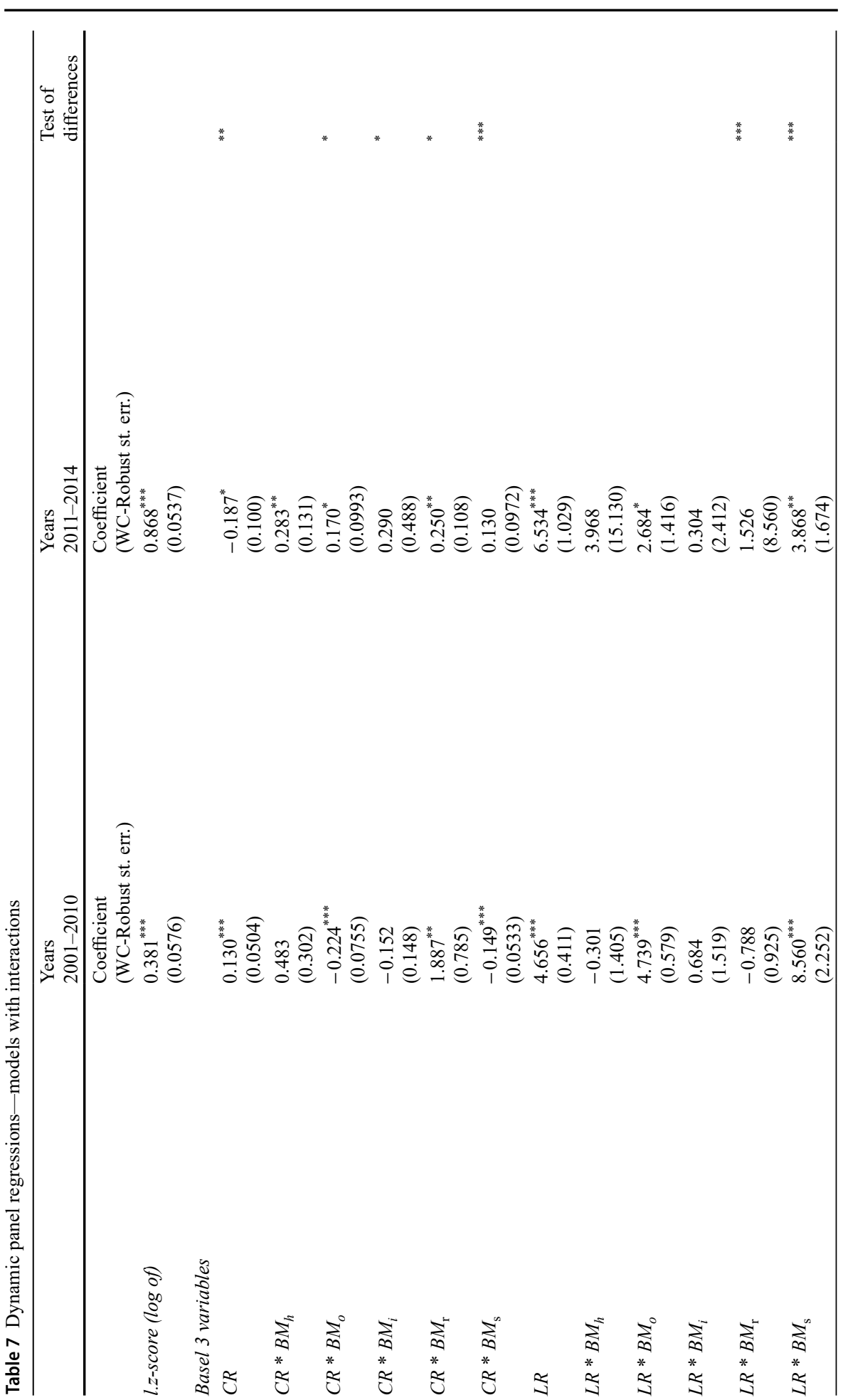




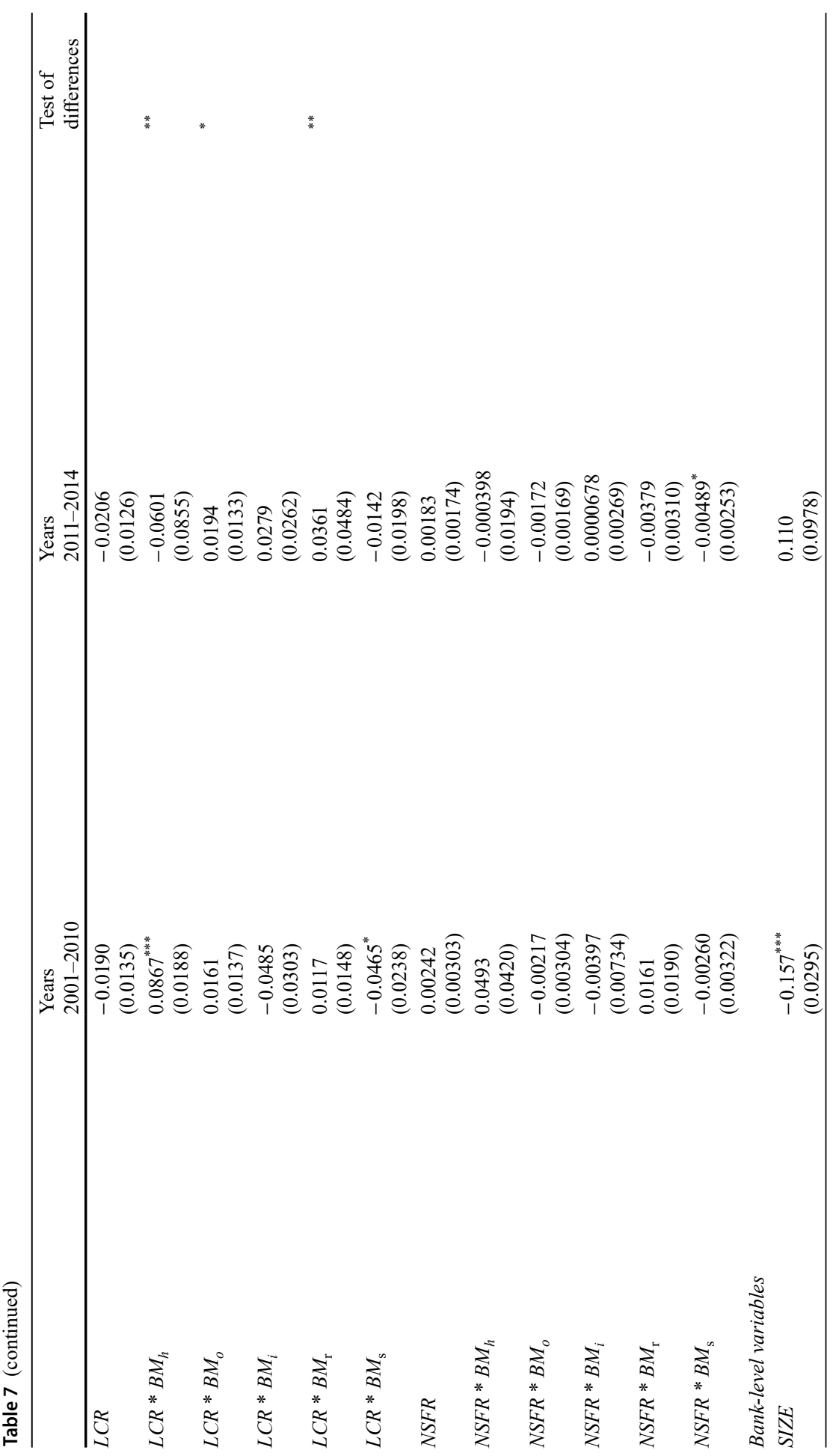




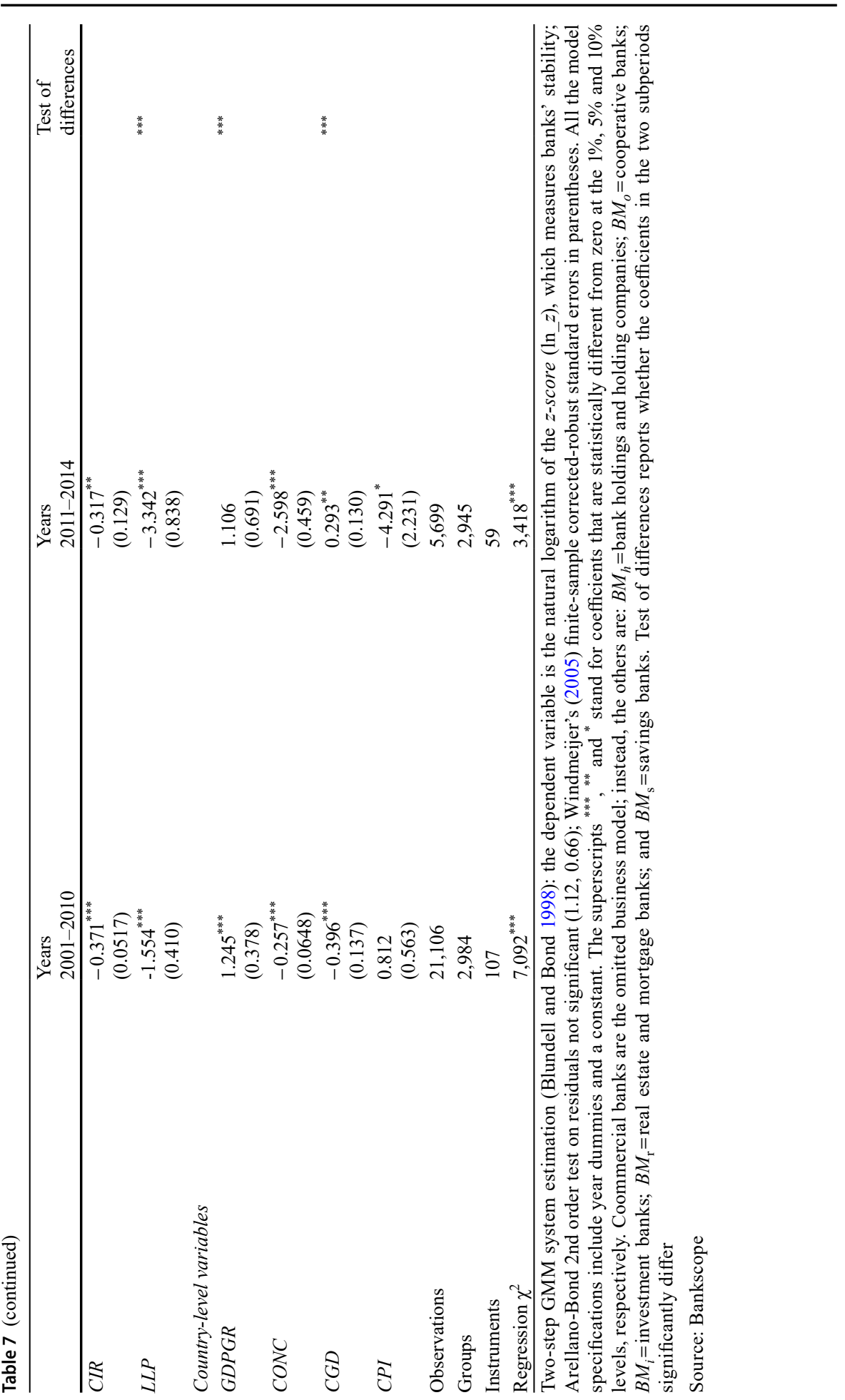


Table 8 Composite effect and difference with the reference category of a contemporaneous variation equal to +1 standard deviation in the Basel 3 variables

\begin{tabular}{|c|c|c|c|c|c|c|}
\hline $\begin{array}{l}\text { Business } \\
\text { model }\end{array}$ & $\begin{array}{l}\mathrm{CE} \\
2000- \\
2010\end{array}$ & $\begin{array}{l}\text { CE } \\
2011- \\
2014\end{array}$ & $\begin{array}{l}\mathrm{CE} \\
\text { Test of } \\
\text { differences }\end{array}$ & $\begin{array}{l}\Delta \\
2000- \\
2010\end{array}$ & $\begin{array}{l}\Delta \\
2011- \\
2014\end{array}$ & $\begin{array}{l}\Delta \\
\text { Test of } \\
\text { differences }\end{array}$ \\
\hline$\overline{B M_{m}}$ & $0.338^{* * *}$ & $0.410^{* * *}$ & * & -- & --- & --- \\
\hline$B M_{h}$ & $1.049^{* *}$ & 0.635 & & 0.711 & 0.225 & * \\
\hline$B M_{o}$ & $0.628^{* * *}$ & $0.629^{* * *}$ & $* * *$ & $0.290^{* * *}$ & $0.219^{* *}$ & $* *$ \\
\hline$B M_{i}$ & $0.250^{* * *}$ & $0.515^{* * *}$ & $* *$ & -0.0882 & 0.105 & \\
\hline$B M_{r}$ & $0.763^{* * *}$ & 0.563 & & $0.425^{* *}$ & 0.153 & \\
\hline$B M_{s}$ & $0.808^{* * *}$ & $0.622^{* * *}$ & $* * *$ & $0.470^{* * *}$ & $0.212^{*}$ & \\
\hline
\end{tabular}

The composite effect is a linear combination of standard deviations with the coefficients of the Basel 3 variables and the interaction terms of each business model. CE stands for the composite effect; $\Delta$ represents the difference between the $\mathrm{CE}$ of each line and the $\mathrm{CE}$ of the first line (commercial banks). The superscripts ${ }^{* * *},{ }^{* *}$ and ${ }^{*}$ stand for the linear combination of coefficients that are statistically different from zero at the $1 \%, 5 \%$ and $10 \%$ levels, respectively. The business models are: $B M_{m}=$ coommercial banks; $B M_{h}=$ bank holdings and holding companies; $B M_{o}=$ cooperative banks; $B M_{i}=$ investment banks; $B M_{\mathrm{r}}=$ real estate and mortgage banks; $B M_{\mathrm{s}}=$ savings banks. Test of differences reports whether the coefficients in the two subperiods significantly differ

sis of the impact of Basel 3 by considering whether and how all four innovations jointly affect banks' riskiness.

Our second research question investigated whether and how strongly Basel 3 requirements affect differently the risk of banks working under diverse BMs. We ran dynamic panel regressions to study banks' stability (z-score), interacting each Basel 3 variable with each bank's BM. By means of these estimations, we simulated a policy based on increases of one standard deviation of the Basel 3 variables.

Among the most interesting results of the base model without interactions, our analysis showed that LR is a positive determinant of banks' stability, unlike CR. On the liquidity side, NSFR and LCR do not contribute to mitigate banks' risk.

Our interactions between banks' BMs and Basel 3 variables identified how Basel 3 innovations affect bank $z$-scores across different BMs. The joint pro-stability effect of the four Basel 3 innovations turns out most intense at savings and cooperative banks, much more than at commercial banks, bank holdings and holding companies, investment banks and real estate \& mortgage banks. This suggests that more focused traditional activity, rather than strategies of diversification, could bolster banks' stability under Basel 3. Also, it is confirmed that banks' BMs are a key driver of banks' risk taking and, in turn, this reinforces the case for Europe to abandon its "one-sizefits-all" rules under CRD IV-CRR.

Our results call for further research on this issue as well. Investigating other geographical macro-areas could enrich the discussion about important differences to consider when discussing financial stability. To this end, comparative studies of areas differing in supervision could offer insight. Finally, the impact of regulation on banks' stability could vary not only across different business models, as our results indicate, but also be nonlinear across different levels of banks' risk.

Funding Open access funding provided by Università del Salento within the CRUI-CARE Agreement. 
Open Access This article is licensed under a Creative Commons Attribution 4.0 International License, which permits use, sharing, adaptation, distribution and reproduction in any medium or format, as long as you give appropriate credit to the original author(s) and the source, provide a link to the Creative Commons licence, and indicate if changes were made. The images or other third party material in this article are included in the article's Creative Commons licence, unless indicated otherwise in a credit line to the material. If material is not included in the article's Creative Commons licence and your intended use is not permitted by statutory regulation or exceeds the permitted use, you will need to obtain permission directly from the copyright holder. To view a copy of this licence, visit http:/creativecommons.org/ licenses/by/4.0/.

\section{References}

Acharya, V.V., Steffen, S.: The greatest carry trade ever? Understanding Eurozone bank risks. NBER Working Paper 19039: (2013)

Acharya, V.V., Shin, H.S., Yorulmazer, T.: Crisis Resolution and Bank Liquidity. Rev. Financial Stud. 24(6), 2166-2205 (2011)

Afonso, A., Baxa, J., Slavík, M.: Fiscal developments and financial stress: a threshold VAR analysis. Empir. Econ. 54(2), 395-423 (2018)

Allen, F., Gale, D.: Financial fragility, liquidity and asset prices. J. Eur. Econ. Assoc. 2(6), 1015-1048 (2004)

Altunbas, Y., Manganelli, S., Marques-Ibanez, D.: Bank Risk during the Great Recession: do business models matter? ECB Working Paper 1394: (2011)

Arellano, M., Bover, O.: Another look at the instrumental variable estimation of error-components models. J. Econom. 68(1), 29-51 (1995)

Arpa, M., Giulini, I., Ittner, A., Pauer, F.: The influence of macroeconomic developments on Austrian banks: implications for banking supervision. BIS Working Paper 1: (2001)

Ayadi, R., Arbak, E., De Groen, W.P.: Business Models in European Banking. A pre — and post—crisis screening. Centre for European Policy Studies, Bruxelles. https://www.ceps.eu/ceps-publications/ business-models-european-banking-pre-and-post-crisis-screening/ (2011). Accessed 20 January 2020

Ayadi, R., Arbak, E., De Groen, W.P.: Regulation of European Banks and Business Models: towards a new paradigm? Centre for European Policy Studies, Bruxelles. https://www.ceps.eu/ceps-publications/ regulation-european-banks-and-business-models-towards-new-paradigm/ (2012). Accessed 23 September 2020

Ayadi, R., De Groen, W.P.: Banking Business Models Monitor 2014 Europe. Centre for European Policy Studies, Bruxelles and International Observatory on Financial Services Cooperatives, HEC Montreal. https://www.ceps.eu/ceps-publications/banking-business-models-monitor-2014-europe/ (2014). Accessed 3 March 2020

Ayadi, R., De Groen, W.P., Sassi, I., Mathlouthi, W., Rey, H., Aubry, O.: Banking Business Models Monitor 2015 Europe. Alphonse and Dorimène Desjardins International Institute for Cooperatives and International Research Centre on Cooperative Finance, HEC Montreal. https:/www.ceps.eu/cepspublications/banking-business-models-monitor-2015-europe/ (2015). Accessed 18 November 2019

Baboucek, I., Jancar, M.: A VAR analysis of the effects to macroeconomic shocks to the quality of the aggregate loan portfolio of the Czech-banking sector. Czech National Bank Working Paper: (2005)

Barth, J.R., Nolle, D.E., Phumiwasana, T., Glenn, Y.: A Cross-Country Analysis of the Bank Supervisory Framework and Bank Performance. Financial Mark. Inst. Instrum. 12, 67-120 (2003)

Basel Committee on Banking and Supervision (BCBS): Basel III: A global regulatory framework for more resilient banks and banking systems. Bank of International Settlement. Revised version. https://www. bis.org/publ/bcbs189.pdf (2011). Accessed 9 September 2019

Basel Committee on Banking Supervision (BCBS): Basel III: the net stable funding ratio. Bank of International Settlement. https://www.bis.org/bcbs/publ/d295.pdf (2014). Accessed 8 July 2020

Basel Committee on Banking Supervision (BCBS): Basel III: The Liquidity Coverage Ratio and liquidity risk monitoring tools. Bank of International Settlement. https://www.bis.org/publ/bcbs238.pdf (2013). Accessed 10 December 2019

Beck, T., De Jonghe, O., Schepens, G.: Bank competition and stability: Cross-country heterogeneity. J. Financial Intermediation 22, 218-244 (2013) 
Beck, T., Demirgüç-Kunt, A., Merrouche, O.: Islamic vs. Conventional Banking Business Model, Efficiency and Stability. The World Bank Policy Research Working Paper 5446: (2010)

Beck, T., Demirgüç-Kunt, A., Levine, R.: Bank concentration, competition, and crises: First results. J. Bank. Finance 30(5), 1581-1603 (2006)

Bhagat, S., Bolton, B., Lu, J.: Size, leverage, and risk-taking of financial institutions. J. Bank. Finance 59, 520-537 (2015)

Blanchard, O.J., Leigh, D.: Growth forecast errors and fiscal multipliers. Am. Econ. Rev. 103(3), 117-120 (2013)

Blundell, R., Bond, S.: Initial conditions and moment restrictions in dynamic panel data models. J. econ. 87(1), 115-143 (1998)

Blundell-Wignall, A., Roulet, C.: Business models of banks, leverage and the distance-to-default. OECD J. Financial Mark. Trends 103 (2013)

Blundell-Wignall, A., Atkinson, P., Roulet, C.: Bank business models and the Basel system: Complexity and interconnectedness. OECD J. Financial Mark. Trends 2 (2013)

Bonfim, D., Kim, M.: Liquidity risk in banking: is there herding? Banco de Portugal Economics and Research Department Working Papers: (October, 2012)

Bordeleau, È, Graham, C.: The Impact of Liquidity on Bank Profitability. Bank of Canada Working Paper 38: (2010)

Bourke, P.: Concentration and Other Determinants of Bank Profitability in Europe, North America and Australia. J. Bank. Finance 13, 65-79 (1989)

Boyd, J.H., De Nicolò, G.: The theory of bank risk taking and competition revisited. J. Finance 60(3), 1329-1343 (2005)

Boyd, J.H., Runkle, D.E.: Size and performance of banking firms. Testing the predictions of theory. J. Monetary Econ. 31, 47-67 (1993)

Boyd, J.H., Graham, S.L.: Risk, regulation and bank holding expansion into nonbanking. Fed. Reserve Bank Minneapolis Q. Rev. 10, 2-17 (1986)

Brei, M., Gambacorta, L.: The leverage ratio over the cycle. BIS Working Paper 471: (2014)

Brunnermeier, M., Garicano, L., Lane, P.R., Pagano, M., Reis, R., Santos, T., Thesmar, D., Nieuwerburgh, S.V., Vayanos, D.: The sovereign-bank diabolic loop and ESBies. Am. Econ. Rev. 106(5), 508-512 (2016)

Chiaramonte, L., Poli, F., Oriani, M.E.: Are Cooperative Banks a Lever for Promoting Bank Stability? Evidence from the Recent Financial Crisis in OECD Countries. Eur. Financ. Manag. 21(3), 491-523 (2015)

Conrad, A., Neuberger, D., Trigo Gamarra, L.: The impact of regional and demographic factors on the efficiency of German savings banks. University of Rostock Working Paper 111: (2009)

Dallari, P., Ribba, A.: The dynamic effects of monetary policy and government spending shocks on unemployment in the peripheral Euro area countries. Econ. Model. 85, 218-232 (2020)

D’Apice, V., Ferri, G., Lacitignola, P.: Rating Performance and Bank Business Models: Is There a Change With the Global Crisis? Italian Economic J.: A continuation of Rivista Italiana degli Economisti and. Giornale degli Economisti 2(3), 385-420 (2016)

De Nicoló, G.: Size, Charter Value and Risk in Banking: an International Perspective. Board of Governors of the Federal Reserve System International Finance Discussion Papers 689: (2000)

Delis, M.D., Hasan, I., Tsionas, E.G.: The risk of financial intermediaries. J. Bank. Finance 44, 1-12 (2014)

Delis, M.D., Kouretas, G.P.: Interest rates and bank risk-taking. J. Bank. Finance 35(4), 840-855 (2011)

Demirgüç-Kunt, A., Detragiache, E.: Basel core principles and bank soundness: does compliance matter? J. Financial Stab 7(4), 179-190 (2011)

Demirgüç-Kunt, A., Detragiache, E., Merrouche, O.: Bank Capital: Lessons from the Financial Crisis. J. Money Credit Bank. 45, 1147-1164 (2013)

Demirgüç-Kunt, A., Huizinga, H.P.: Bank Activity and Funding Strategies. The Impact on Risk and Returns. The World Bank Working Paper 4837: (2009)

Demirgüç-Kunt, A., Laeven, L., Levine, R.: The Impact of Bank Regulations, Concentration, and Institutions on Bank Margins. The World Bank Development Research group Finance, Policy Research Working Paper 3030 (April, 2003)

Dermine, J.: Basel III Leverage Ratio Requirement and the Probability of Bank Runs. J. Bank. Finance 53, 266-277 (2015)

Dietrich, A., Hess, K., Wanzenried, G.: The good and bad news about the new liquidity rules of Basel III in Western European countries. J. Bank. Finance 44, 13-25 (2014) 
Distinguin, I., Roulet, C., Tarazi, A.: Bank Regulatory Capital and Liquidity: Evidence from U.S. and European publicly traded banks. J. Bank. Finance 37(9), 3295-3317 (2013)

Dosi, G., Fagiolo, G., Napoletano, M., Roventini, A., Treibich, T.: Fiscal and monetary policies in complex evolving economies. J. Economic Dynamics and Control 52, 166-189 (2015)

European Banking Authority (EBA): Second report on impact assessment for liquidity measures under Article 509(1) of the CRR. https://www.eba.europa.eu/documents/10180/950548/2014+LCR+IA+re port.pdf (December, 2014). Accessed 20 April 2020

European Central Bank (ECB): Financial Stability Review. https:/www.ecb.europa.eu/pub/pdf/other/ financialstabilityreview201511.en.pdf (November, 2015). Accessed 10 October 2019

European Banking Authority (EBA): Overview of the potential implications of regulatory measures for banks' business models. https://www.eba.europa.eu/documents/10180/974844/Report+-+Overvie $\mathrm{w}+\mathrm{of}+$ the+potential+implications+of+regulatory+measures+for+business+models.pdf/fd839715ce6d-4f48-aa8d-0396ffc146b9 (February, 2015). Accessed 25 May 2020

Fang, Y., Hasan, I., Marton, K.: Institutional development and bank stability: Evidence from transition countries. J. Bank. Finance 39, 160-176 (2014)

Farhi, E., Golosov, M., Tsyvinski, A.: A theory of liquidity and regulation of financial intermediation. Rev. Economic Stud. 76(3), 973-992 (2009)

Ferri, G., Pesic, V.: Bank regulatory arbitrage via risk weighted assets dispersion. J. Financial Stab. 33, 331-345 (2017)

Fiordelisi, F., Ibanez, D.M., Molyneux, P.: Efficiency and risk in European banking. European Central Bank Working Paper Series 1211: (2010)

Furfine, C.: Bank portfolio allocation: the impact of capital requirements, regulatory monitoring and economic conditions. J. Financial Services Res. 20, 33-56 (2001)

Giordana, G.A., Schumacher, I.: An Empirical Study On The Impact Of Basel III Standards On Banks' Default Risk: The Case Of Luxembourg. Banque centrale du Luxembourg Working Paper 79 (October, 2012)

Gobat, J., Yanase, M., Maloney, J.: The Net Stable Funding Ratio: Impact and Issues for Consideration. IMF Working Paper 106: (2014)

Haldane, A.G., Madouros, V.: The dog and the frisbee. Rev. de Econ. Inst. 14(27), 13-56 (2012)

Hannan, T.H., Hanweck, G.A.: Bank insolvency risk and the market for large certificates of deposit. J. Money Credit Bank. 20, 203-211 (1988)

Hesse, H., Čihák, M.: Cooperative Banks and Financial Stability. IMF Working Paper 2: (2007)

Hong, H., Huang, J.Z., Wu, D.: The information content of Basel III liquidity risk measures. J. Financial Stab. 15, 91-111 (2014)

Hryckiewicz, A.: Originators, Traders, Neutrals, and Traditioners - Various Banking Business Models Across the Globe: Does the Business Model Matter for Financial Stability? MPRA Paper 55118. University Library of Munich, Germany (March (2014)

Johnston, A., Regan, A.: European monetary integration and the incompatibility of national varieties of capitalism. J. Common Mark. Stud. 54(2), 318-336 (2016)

Kashyap, A.K., Stein, J.C., Wilcox, D.W.: Monetary Policy and Credit Conditions: Evidence from the Composition of External Finance. Am. Econ. Rev. 83(1), 78-98 (1993)

Kasselaki, M.T., Tagkalakis, A.O.: Financial soundeness indicators and financial crisis episodes. Ann. Finance 10, 623-669 (2014)

Khafagy, A.: Regulation, supervision and deposit insurance for financial cooperatives: an empirical investigation. Ann. Finance 14, 143-193 (2018)

King, M.R.: The Basel III net stable funding ratio and bank net interest margins. J. Bank. Finance 37(11), 4144-4156 (2013)

Köhler, M.: Does Non-Interest Income Make Banks More Risky? Retail- vs. Investment-Oriented Banks. Rev. Financial Econ. 23, 182-193 (2014)

Köhler, M.: Which Banks are More Risky?, The impact of business models on bank stability. J. Financial Stab. 16, 195-212 (2015)

Kosmidou, K., Tanna, S., Pasiouras, F.: Determinants of Profitability of Domestic UK Commercial Banks: Panel Evidence from the Period 1995-2002. Money Macro and Finance (MMF) Research Group Conference: (2005)

Kowalik, M.: Basel liquidity regulation: was it improved with the 2013 revisions? Federal Reserve Bank of Kansas City Economic Review, 65-87 (2013)

Kupiec, P.H.: Financial Stability and Basel II. Ann. Finance 3, 107-130 (2007) 
Kwan, S., Eisenbeis, R.A.: Bank risk, capitalization and operating efficiency. J. Financial Services Res. 12, 117-131 (1997)

Laeven, L., Levine, R.: Bank governance, regulation and risk taking. J. Financial Economics 93, 259-275 (2009)

Lepetit, L., Strobel, F.: Bank insolvency risk and Z-score measures: A refinement. Finance Res. Letters 13, 214-224 (2015)

López-Espinosa, G., Moreno, A., Rubia, A., Valderrama, L.: Short-term Wholesale Funding and Systemic Risk: A Global CoVaR Approach. IMF Working Paper 46: (2012)

Maechler, A.M., Mitra, S., Worrell, D.: Decomposing financial risks and vulnerabilities in Eastern Europe. IMF Working Paper 248: (2007)

Marcus, A.J.: Deregulation and bank financial policy. J. Bank. Finance 8, 557-565 (1984)

Mariathasan, M., Merrouche, O.: The Manipulation of Basel Risk-Weights. J. Financial Intermediation 23, 300-321 (2014)

Molyneux, P., Thornton, J.: Determinants of European Bank Profitability: A Note. J. Bank. Finance 16, 1173-1178 (1992)

Ötker-Robe, İ, Pazarbasioglu, C.: Impact of Regulatory Reforms on Large and Complex Financial Institutions. International Monetary Fund-Monetary and Capital Markets Department. https://www. elibrary.imf.org/view/journals/004/2010/016/article-A001-en.xml (November, 2010). Accessed 13 March 2020

Poghosyan, T., Čihák, M.: Distress in European Banks. IMF Working Paper 9: (2009)

Repullo, R., Suarez, J.: The procyclical effects of bank capital regulation. Rev. Financial Stud. 26(2), 452-490 (2013)

Russo, V., Lagasio, V., Brogi, M., Fabozzi, F.J.: Application of the Merton model to estimate the probability of breaching the capital requirements under Basel III rules. Ann. Finance 16, 141-157 (2020)

Scalia, A., Longoni, S., Rosolin, T.: The Net Stable Funding Ratio and banks' participation in monetary policy operations: some evidence for the euro area. Questioni di Economia e Finanza (Occasional paper 195), Banca d'Italia (September, 2013)

Shen, C.H., Chen, T.S.: Performance Analysis of Liquidity Indicators as Early Warning Signals. HKIMR Working Paper 30: (2014)

Shen, C.H., Kuo, C.J., Chen, H.J.: Determinants of Net Interest Margins in Taiwan Banking Industry. J. Financial Stud. 9(1), 47-83 (2001)

Shim, J.: Bank capital buffer and portfolio risk: The influence of business cycle and revenue diversification. J. Bank. Finance 37, 761-772 (2013)

Stiroh, K.J.: New Evidence on the Determinants of Bank Risk. J. Financial Services Res. 30(3), 237-263 (2006)

Tirole, J.: Illiquidity and all its friends. J. Economic Literature 49(2), 287-325 (2011)

Uhde, A., Heimeshoff, U.: Consolidation in banking and financial stability in Europe: Empirical evidence. J. Bank. Finance 33, 1299-1311 (2009)

Van den End, J.W., Kruidhof, M.: Modelling the liquidity ratio as macroprudential instrument. J. Bank. Regulation 14(2), 91-106 (2013)

Van Ewijk, S., Arnold, I.: How bank business models drive interest margins: Evidence from U.S. banklevel data. DNB Working Paper 387: (2013)

Van Oordt, M.R.C., Zhou, C.: Systemic risk and bank business models. De Nederlandsche Bank, DNB Working Paper 442: (2014)

Vázquez, F.F., Federico, P.: Bank funding structures and risk: Evidence from the global financial crisis. J. Bank. Finance 61, 1-14 (2015)

Vives, X.: Strategic Complementarity, Fragility, and Regulation. CEPR Discussion Paper 8444: (2011)

Wagner, W.: The liquidity of bank assets and banking stability. J. Bank. Finance 31, 121-139 (2007)

Williams, J.: Determining management behaviour in European banking. J. Bank. Finance 28, 2427-2460 (2004)

Windmeijer, F.: A finite sample correction for the variance of linear efficient two-step GMM estimators. J. econometrics 126(1), 25-51 (2005)

Yan, M., Hall, M.J.B., Turner, P.: A cost-benefit analysis of Basel III: Some evidence from the UK. Int. Rev. Financial Anal. 25, 73-82 (2012)

Publisher's Note Springer Nature remains neutral with regard to jurisdictional claims in published maps and institutional affiliations. 


\section{Authors and Affiliations}

\section{Giuliana Birindelli ${ }^{1} \cdot$ Paola Ferretti ${ }^{2} \cdot$ Giovanni Ferri $^{3} \cdot$ Marco Savioli $^{4}$}

Marco Savioli

marco.savioli@unisalento.it

Giuliana Birindelli

giuliana.birindelli@unich.it

Paola Ferretti

paola.ferretti@unipi.it

Giovanni Ferri

g.ferri@lumsa.it

1 Department of Management and Business Administration, University of Chieti-Pescara, Chieti-Pescara, Italy

2 Department of Economics and Management, University of Pisa, Pisa, Italy

3 Department of Law, Economic \& Political Sciences \& Modern Languages, LUMSA University of Rome, Rome, Italy

4 Department of Economics, University of Salento \& Rimini Centre for Economic Analysis, Lecce, Italy 